\title{
Towards new traditional urban fabrics: Learning from London
}

\author{
Mario Gallarati \\ Gallarati Architetti, Genova, Italy \\ E-mail: m.gallarati@gallaratiarchitetti.com
}

\begin{abstract}
Today's towns, as often represented on the web and media, seem almost the same, flattened out on the American model. But European towns still preserve their individuality: if we look at aerial views, for instance, we can see that just little sections are enough to make it impossible to confuse them. And it is not because of some single building or monument. Each of these towns has its own character due to the very nature of its urban fabric. Furthermore, every town is made of several different urban fabrics, each one with its own specific character, which distinguishes it from the others: nevertheless all of them appear as different aspects of the same reality. Which are the common features connecting such apparently different realities? And how can we learn from the past in order to obtain a more livable built environment, in coherence with the traditional town and without interrupting but even promoting its further development?
\end{abstract}

Keywords: Urban Fabrics, London Squares, Traditional Town, Built Environment

\section{Introduction}

What kind of mental representation do people have of today's towns? Both the media and the web give them pictures showing multitudes of iron-glass skyscrapers, often represented in night views, where the towns may even appear beautiful in their sparkling aspect. But in night or day views they seem all alike, flattened out on the American model. Thus, comparing different towns like that, it's very difficult to identify them.

In the case of London, the object of our research, only a few elements allows us to do it, for example the presence of the river Thames and some small differences between Norman Forster's skyscraper and the similar ones in Barcelona and Tokyo. Let's look at some aerial views of XVII-XIX centuries European towns: in most cases just little sections are often enough to make it impossible to confuse them. And it is not necessarily because of some single building or monument.

Each of these towns has its own character due to the very nature of its urban fabric. That is to say the set of typical features (relationship between streets, plots layout, building types and architectural characters) that identifies every single town making it different from all the others. Although designed and realized in a rather short period and in similar social and cultural contexts, these towns seem quite different one another. Some of them may seem a little monotonous, but all of them have a high degree of urban quality.

This paper represents a new step of my practice's research on traditional urban fabrics in the European cities, started in 2013 and mainly focused on London's fabrics and squares. The choice of London as subject matter has been made taking into consideration the fact that most of the present central neighborhoods were built in a rather short time, from the 1666 Great Fire to the Second World War. They represent one of the largest examples of homogeneous urban growth over a shared building language time. But, although homogeneous, London is not just the same everywhere. 
Even if a great part of the town center is made of several different XVIII-XIX century urban fabrics, each one of them has its own specific character, which distinguishes it from the others. And yet, even if so different, no doubt they all are London.

Look at some aerial views of the central London urban fabric: despite the variety of the individual solutions, they share the same general characters, no matter the time of their construction and the different style of their architecture.

The same we can say about eye-level pictures, showing different street fronts. At the building scale, the differences are even greater, both for the building type's progress (from individual homes to apartments blocks) and for the stylistic changes (from Georgian houses to Victorian ones): nevertheless all of them appear as different aspects of the same reality. And also in this case, no doubt they all are London.

So, which are the common features connecting such apparently different realities? And how can we learn from the past in order to obtain a more livable built environment, in coherence with the traditional town and without interrupting but even promoting its further development?

\section{The formation of London square and urban fabric types.}

As we have already seen in some previous reports, we started our research with the close exam of the existing urban fabrics and in particular of the traditional ones. A good basis is given by the 1799 Richard Horwood's Plan of the Cities of London and Westminster, the Borough of Southwark and Parts Adjoining, which is a very detailed map of Georgian London, showing, in many parts of the town at least, besides every house, the allotment of the building land.

If we superimpose this map to a more recent Google map, we realize that while a great part of the town did undergo a deep change, some significant sectors of the old urban fabric still remain, particularly in central-western London, even though many of their buildings have been replaced during the last two centuries. Most of them coincide with the first group of great planned developments that from the second half of the XVII century to the end of the XVIII century began to give London its present urban character.

Each of these developments depends (in part, at least) on an orthogonal street fabric, focusing on an open space, usually a garden square. These squares, often surrounded by uniform buildings after the tradition of the Italian (and then French and Spanish) Renaissance architectural squares, represent perhaps the most connotative elements of London urban fabric. We have pointed out, on Horwood's map and then on the Google map, all the garden squares realised from 1631 to 1799 and still existing, although transformed.

Starting from the late Renaissance Inigo Jones's Covent Garden, we may count up to 30 garden squares (plus three crescent squares Great Cumberland Place, Highbury Crescent, The Paragon) existing at the end of the XVIII century:

$\begin{array}{ll}\text { XVII century: } & \\ \begin{array}{l}\text { Covent Garden } \\ \text { Lincoln's Inn Fields }\end{array} & 1631 \text { onwards } \\ \begin{array}{l}\text { Bloomsbury Square } \\ \text { St. James's Square }\end{array} & 1661 \text { onwards } \\ \begin{array}{l}\text { Golden Square } \\ \text { Devonshire Square }\end{array} & 1670 \text { onwards } \\ 1678 \text { onwards } \\ \text { Soho Square } & 1681 \text { onwards } \\ \text { Hoxton Square } & 1683 \text { onwards } \\ \begin{array}{l}\text { New Square } \\ \text { (Old Square) }\end{array} & 1683 \text { onwards } \\ \begin{array}{l}\text { Red Lion Square } \\ \text { Kensington Square }\end{array} & 1684 \text { onwards } \\ \text { (King's Square) } & 1685 \text { onwards } \\ \begin{array}{l}\text { Grosvenor Square } \\ \text { Gray's Inn Square }\end{array} & 1695 \text { onwards } \\ 1699 \text { onwards }\end{array}$

XVIII century:

Queen Square 1716 onwards

Smith Square 1713 onwards

Hanover Square 1717 onwards

Cavendish Square 1717 onwards

Charterhouse Square 1722 onwards

Berkeley Square 1739 onwards

Portman Square 1764 onwards

Sloane Square 1771 onwards 


$\begin{array}{ll}\begin{array}{l}\text { Great Cumberland P1 } 1774 \text { onwards } \\ \text { Bedford Square } \\ \text { Manchester Square }\end{array} & 1775 \text { onwards } \\ \begin{array}{l}\text { Hans Place } \\ \text { (1870's rebuilt) }\end{array} & 1770 \text { 's } \\ \begin{array}{l}\text { Highbury Crescent } \\ \text { Cleaver Square }\end{array} & 1770 \text { 's } \\ \begin{array}{l}\text { (Prince's Square) } \\ \text { Gloucester Circus }\end{array} & 1789 \text { onwards } \\ \begin{array}{l}\text { West Square } \\ \text { Fitzroy Square }\end{array} & 1791 \text { onwards } \\ \text { The Paragon } & 1792 \text { onwards } \\ \begin{array}{l}\text { Brunswick Square } \\ \text { Surrey Square }\end{array} & 1795 \text { onwards } \\ \text { (almost demolished) } & 1795 \text { onwards }\end{array}$

We have then examined the main characters of these squares, so as to find out the elements they have in common: the same elements may lately have influenced the many building developments of the XIX (and first XX) C., which transformed London into one of the great European capital cities.

On the basis of the same Horwood's map, we have pointed out the street system upon which the single squares plans are based, the possible presence of special buildings, the layout of the plots and houses that surround them and the sections of urban fabric that seem to be strictly connected to the same squares. Some squares, like the early XVII century ones, appear to be the simple reorganization of wide areas inside pre-existing urban fabrics alongside suburban roads. Others, instead, seem to be the focus elements of widely extended building developments, based on a new street network, along which the same building organization and homogeneous architecture of the square are proposed again. Some refer to special buildings (churches or palaces) and their plans tend to be symmetrical on a central axis. Others seem to depend chiefly on the street axis connecting them to the main roads. None of them lays at the intersection of pre-existing main roads. All of them are surrounded by rows of serial buildings, typologically homogeneous and composing uniform fronts. More in detail, we can notice that the new developments are almost always separated from the main roads by the pre-existing fabrics, seldom involved in the new interventions.
So, the new urban fabrics and squares lay on the back of what we call the pertinent stripe, including all the built lots referred to the same street front of the pre-existing streets. For this reason the layout of the squares depends firstly on the streets which connect them to the same main roads.

In some cases the connecting street becomes the central axis of the square, with or without the presence of emerging buildings (see for instance Bloomsbury, Soho, Hanover, Cavendish, West and Manchester squares). In others, two streets connect the square to the main road: they don't play the part of spatial axis but just define the building line of the new row houses (see St. James's, Golden, Berkeley, Cleaver and Fitzroy squares). In others again, the layout of the square is defined by two couples of orthogonal streets that become the matrix of the surrounding urban fabrics (see Portman, Grosvenor and Bedford squares). We've then tried to go deeper into the structure of the same squares, pointing out the organisation of the plots and buildings that surround the squares and the nearby streets. Besides the layout of the squares and streets, the most relevant element seems to be the division into plots of the building land. We may outline different urban fabric types, seen as aggregative system of several building types.

-Simple fabrics: just one stripe of built plots alongside a street (see for instance Bloomsbury Square, Queen Square, or Bedford Square);

-Double fabrics: two stripes of built plots, facing parallel streets and bordering each other at their back (see Bloomsbury, Queen and West squares);

-Simple fabrics with stables: one stripe of built plots, with row houses facing the street and stables on the back (see Bedford Square again or Lincoln's Inn Fields);

-Double fabrics with stables and mews: two stripes of built plots, each with row houses facing the street and stables on the back, separated by common mews (see Portman, Grosvenor and Bedford squares).

The depth of the plots varies from about 75' to 150 ' for what concerns the single tissues without stables; it is usually greater up to 180 '200 ' for the single tissues with stables; these dimensions redouble, in case of double fabrics, and even more in the presence of mews. 

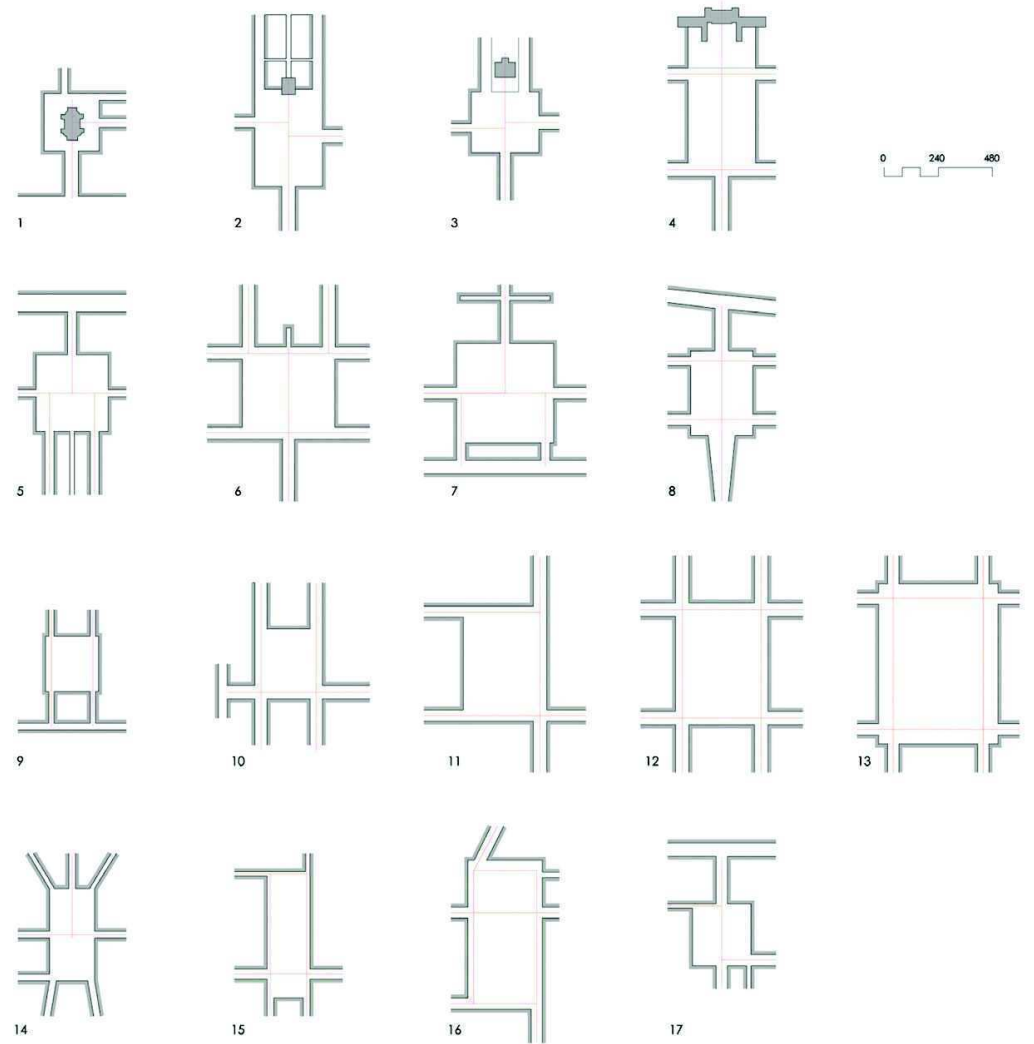

Figure 1.

London squares general layout schemes @ GALLARATI ARCHITETTI.

As for their width, it varies much more according to the building types and seems to be proportional to the depth of the houses:

-a $16^{\prime}$ average width is typical of the spontaneous building fabrics along the preexisting roads, but we can find it in some planned new suburban tissues (see West or Cleaver squares): it corresponds to the twobays (or even one-bay) house-type;

-a 24' to 32' width corresponds to the threebays house-type, that seems to be the base type of many of the XVII - XVIII century developments (still very well preserved in Bedford Square, for instance);

-a 32' to 48 ' width corresponds to the fourfive bays house-types, a multiple of the first two types: they often seem to be derived from the unification of two smaller buildings or plots (see for instance Portman or Smith squares), but in some interventions they have been directly used as new base types (see St. James's and Cavendish squares);

-lastly, a 50' to 70' width is the dimension of the largest five-six bays, or more, house-types, multiples of two or three of the previous base types (see Hanover, Portman and Grosvenor squares).

We have so far pointed out only the deep structure of these XVII-XVIII century developments: but, how do they present themselves? What kind of formal settlement do they have? As we have seen, most of them have been transformed and their houses often gradually substituted by others with more and more increased dimensions up to include in one single building the whole width of the square front (Portman, Grosvenor, Bloomsbury squares). Basing our vision on the best preserved squares (Bedford, West, Cleaver squares), we may argue that most of the squares were conceived to be homogeneous, composed by the serial repetition of a same single element, the same single building type. To each building type corresponds a specific front elevation, whose rhythmical repetition alongside the entire row gives it its uniform architectural character. Therefore, the squares' architectural uniformity is given by the rhythmical repetition of analogous elements. 
Rhythm may be uniform (A-A-A-A) or alternate (A-A'-A-A').

Sometimes a particular accent (a pediment, for instance) is given to the central element of the row, so as to give an axis to the square (see Bedford and West squares). With the progressive substitution of the original houses much of this character has been lost but we may find it again in most of the great XIX century realizations. In the next 4 synoptic plates we have tried to summarize the main elements we have observed until now.

1. General layout (Fig. 1):

squares with a central axis and a main building on it;

squares with a central axis, without main buildings;

squares with one or two couples of orthogonal axis;

square with occasional axis system.

\section{Urban fabric types:}

simple fabrics;

double fabrics;

simple fabrics with stables;

double fabrics with stables and mews.

\section{Urban fabric cross sections (Fig. 2):}

the progressive development of the urban fabric, from the basic to the most elaborate ones.

\section{Street fronts:}

the gradual development of the street fronts, related to the progress of the building types and to their rhythmical repetition.

This is only a first draft, but we believe it could be a good guideline for deeper analysis of the urban XVII-XVIII century fabrics and the starting point for a wider study of the XIX century great developments and of the fewer XX-XXI century ones.

The development of urban unit types

Since the beginning of the XIX Century on, the development of new urban fabrics and

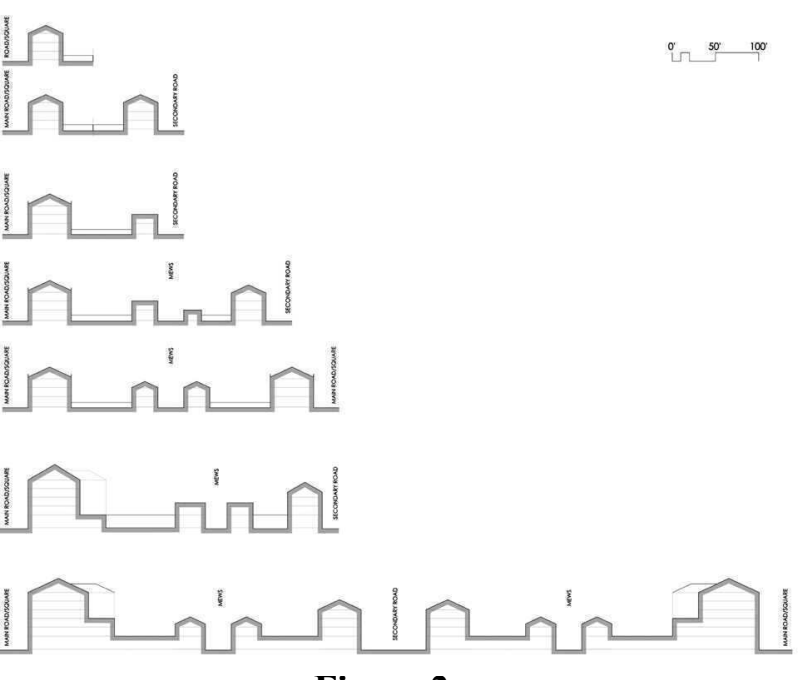

Figure 2.

London fabrics typical cross sections C GALLARATI ARCHITETTI.

garden squares blew up.

From our point of view, the starting point may be considered the opening of Bedford Place in 1800 (after the demolition of Bedford Palace) and its connection to the new Russel Square, that launched the great Bloomsbury development north of Bloomsbury Square. In this case a good basis is given by the 1893-96 Ordnance Survey, Five feet to the mile London map, which shows us the detailed situation of London urban fabrics at the end of XIX C.

We could count up to 206 new garden squares (often called simply gardens in the second half of the Century), circuses, crescents, realised during the XIX century, plus 13 at least in the $\mathrm{XX}$ and 2 in the first years of the XXI century, all matching more or less the main characters we have found out in the 30 previous examples.

The new developments, often involving wide estates, usually have elaborate plans with many squares and streets on whose basis the urban fabrics are organised; they are always characterised by the presence of extended private and public green areas; the architecture of the houses that compose the single urban fabrics tends to be homogeneous.

Also because of their extension, they still stand as the main elements of London present urban morphology. But they are not the same.

If we examine some of the largest and most elaborate urban expansions, we can see that the new fabrics developed in two very different, although almost simultaneous, ways. 
From the very beginning, there seem to be two ways of conceiving the urban growth:

- $\quad$ an intensive way, with a well-structured system of streets and squares and elaborate fabrics, with a clear relationship among the different house-types and the succession of main roads, secondary roads, lanes and mews (see for instance Bloomsbury, Paddington and Belgravia developments, but also Portman, Cadogan etc.);

- an extensive way, with a more "naturalistic" street and square system and simple fabrics aligned along the same street and square fronts (see Kensington, Clerkenwell, Barnsley developments, but also Chelsea, Notting Hill, etc.).

Both of them are definite London ways.

The second way, a proto-type of the late XIX Century Garden City movement, still enjoys some chance, mainly in some minor centre and suburban developments.

The first way instead (that could better match the actual demand) seems to have been abandoned, at least at the moment, leaving the way clear for "modernist" intensive developments.

Let's now examine more in detail some XIX C. London great planned developments. Their morphology may vary according to four main
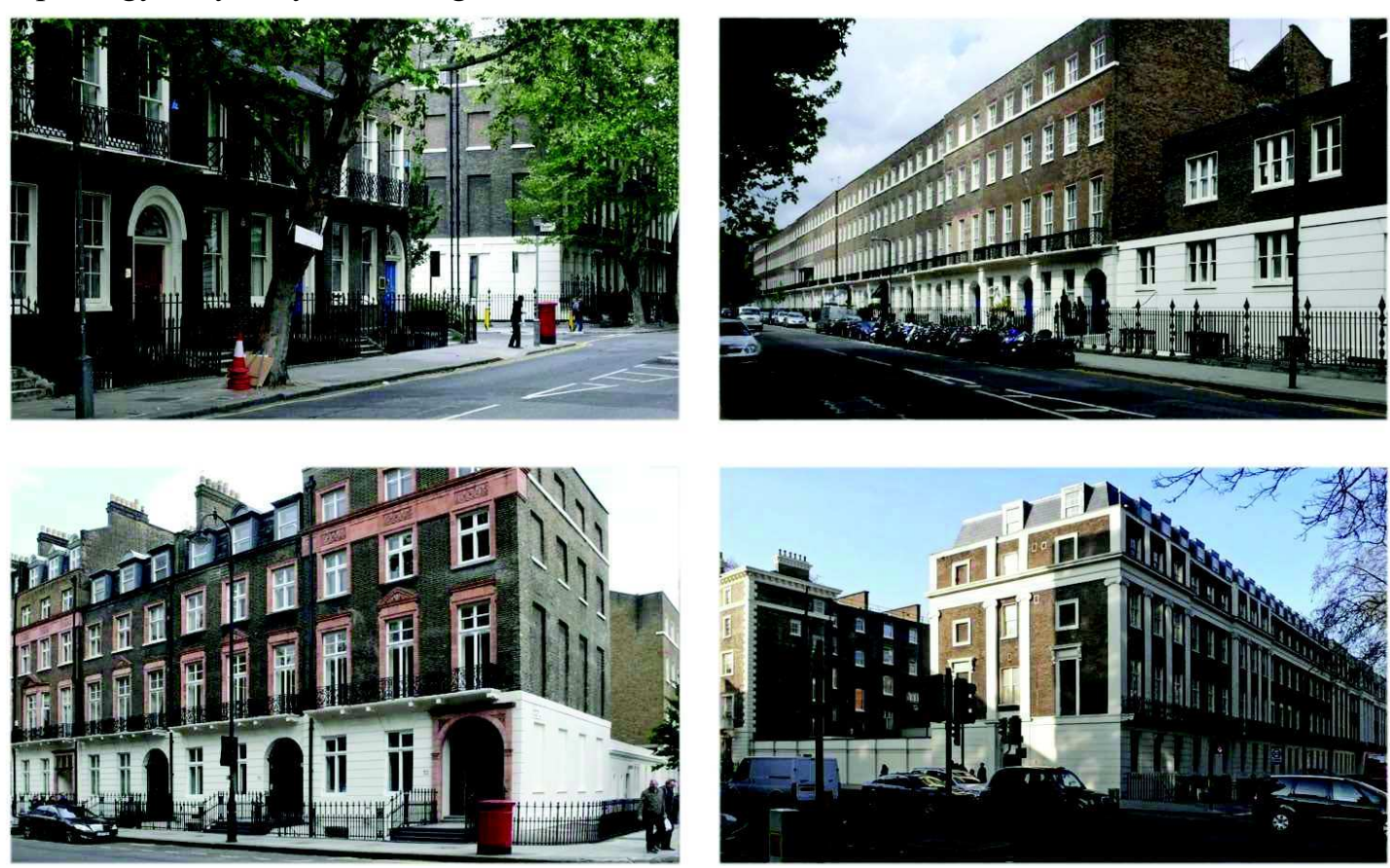

Figure 4.

Bloomsbury development: Bloomsbury Square, Bedford Place, Russel Square, Gordon and Tavistock Squares $\odot$ GALLARATI ARCHITETTI. 
urban unit types:

- low density linear fabrics (two rows of plots and houses alongside a route), linked up one another in a loose and apparently casual street system;

-high density serial fabrics, a close system of main and secondary streets (each one with its own two strips of plots and houses) able to take the best advantage of the available land;

- low density simple polarized fabrics: a loose system of squares (surrounded by simple rows of houses) and streets (with two strips of plots and houses);

-high density organic polarized fabrics: a complex and hierarchical system of squares (primary and secondary poles), streets (main and secondary axes) and mews.

As we have focused our research on London squares we've tried to better analyse type 3, simple polarized fabrics, and type 4 , organic polarized fabrics, corresponding the first to the extensive way of conceiving the urban growth and the second to the intensive one.

In particular in a previous report we had examined the Clerkenwell development (type 3 ) and the Belgravia development (type 4), both realized in the first half of XIX C.

Let's now examine two other examples, the Bloomsbury development, in the first three
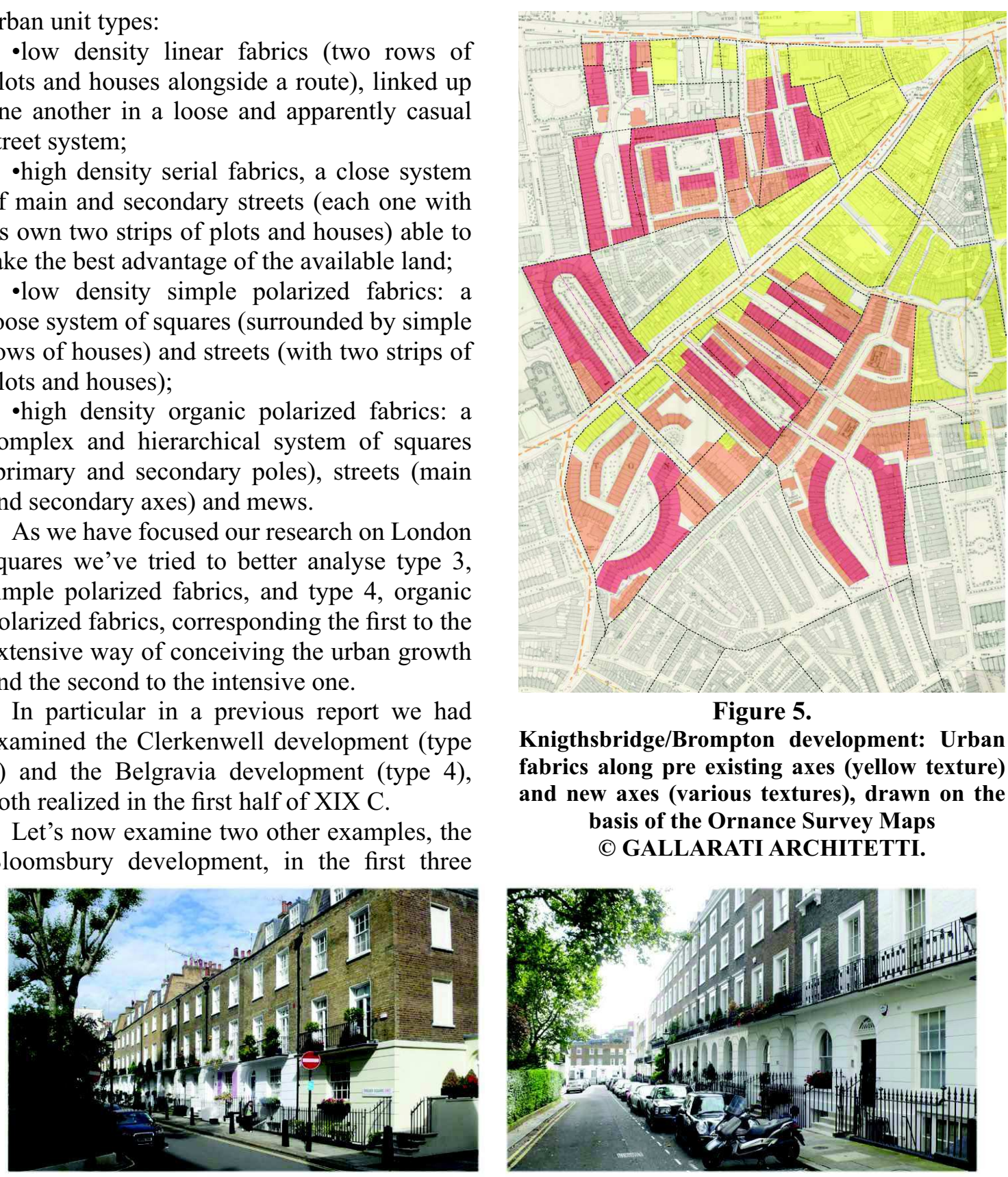

Figure 5.

Knigthsbridge/Brompton development: Urban fabrics along pre existing axes (yellow texture) and new axes (various textures), drawn on the basis of the Ornance Survey Maps (c) GALLARATI ARCHITETTI.
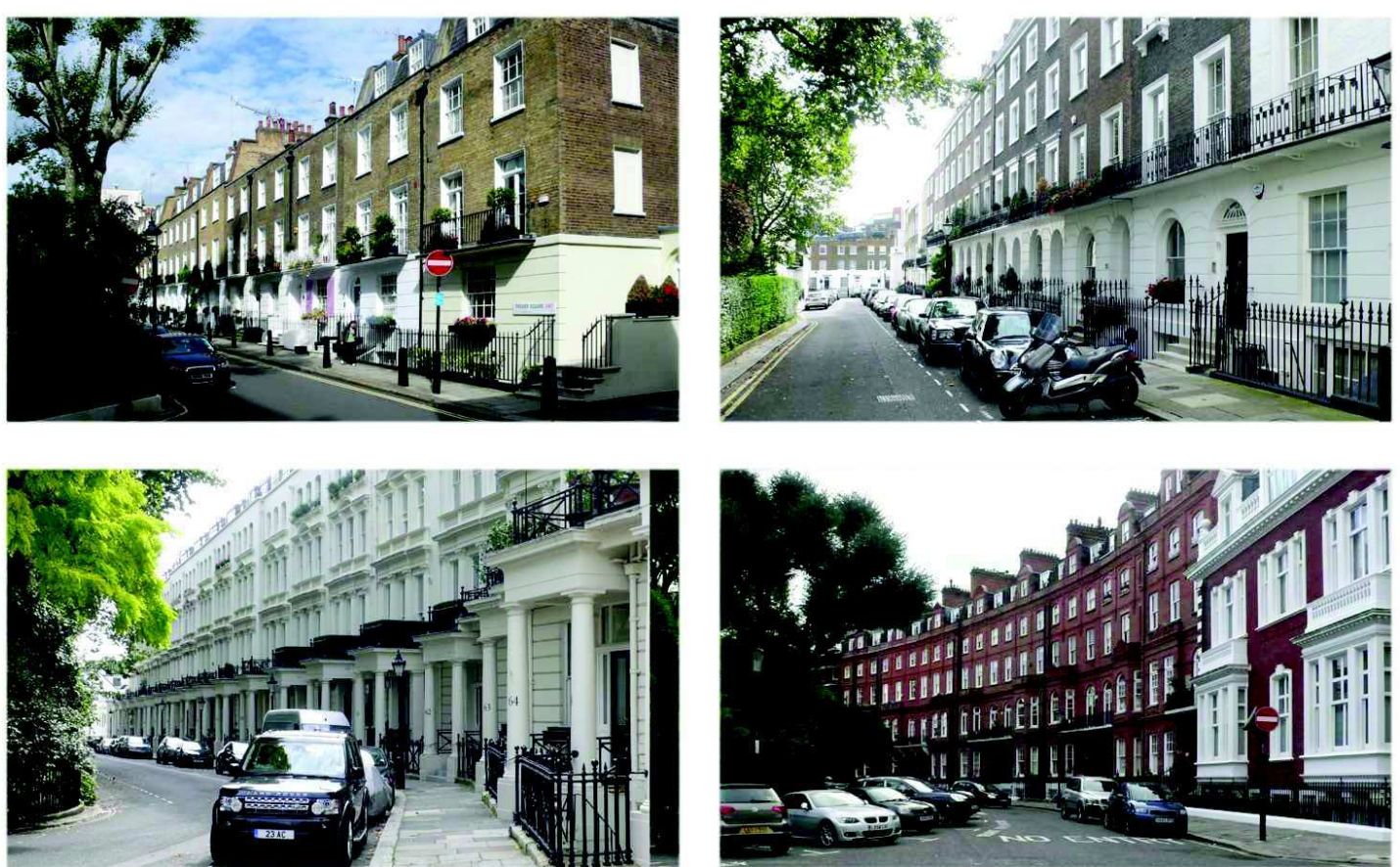

Figure 6.

Knigthsbridge/Brompton development: Trevor Square, Montpellier Square, Rutland Gate, Lennox Gardens () GALLARATI ARCHITETTI. 
decades of XIX C., and the Knightsbridge/ Brompton development, in the immediately following years.

The Bloomsbury development (Fig. 3, 4), within the Bedford Estate, includes the preexisting Bloomsbury (1661) and Bedford (1775) squares and the following new ones:

$\begin{array}{ll}\text { Russel Square } & 1800 \text { onwards } \\ \text { Bedford Place } & 1801 \text { onwards } \\ \text { Gordon Square } & 1820 \text { onwards } \\ \text { Tavistock Square } & 1820 \text { onwards } \\ \text { Torrington Square } & 1821 \text { onwards } \\ \text { Woburn Square } & 1829 \text { onwards }\end{array}$

In its original layout Bloomsbury Square used to be organized along a central axis, focused on a main building (Bedford Palace). With the demolition of the same palace, the axis of the square became the main axis of a greater development, corresponding to the new Bedford Place (opened in 1801 and connecting Bloomsbury Square and Russel Square) and Upper Bedford Place (connecting Russel Square to Tavistock Square) and then to the north-west to Euston Square (later completely demolished and transformed).

In this case the boundary lines are given by one preexisting external road (Southampton Row, to the East), and the rear side of a preexisting building tissue facing Gower Street and Bedford Square.

The new urban fabric is organized, at first, by the squares, which are all bordered by homogeneous terraced houses on their four sides; the remaining tissues lay alongside streets parallel to the main axis: the same Southampton Row; Southampton StreetBloomsbury Square-Bedford Place-Russel Square-Upper Bedford Street and then side of Tavistock Square; Montague Street-side of Russel Square-Woburn Square-side of Gordon Square.

These road axes are laid out according to a close hierarchy B-c-A-c-B on which basis the urban fabric and the building types vary: from the simple fabrics composed alongside Bloomsbury and Russel Square, to the double fabrics between Tavistock and Gordon squares, to the double fabrics with stables and mews alongside Bedford Row and Upper Bedford Row.
As in many other London developments, the mews houses, once just stables on the back of the main buildings, are now independent dwellings, in some ways more similar to village houses than to city houses. The succession of main houses and mews houses gives the urban fabric a new variety and wealth, which can be resumed for further high-density developments.

The Knightsbridge/Brompton (East Kensington) development (Fig. 5,6) is made up of several smaller ones, corresponding to different estates; many of them have road axis, a couple of boundary roads and a central square:

$\begin{array}{ll}\text { Trevor Square } & 1818 \text { onwards } \\ \text { Brompton Square } & 1821 \text { onwards } \\ \text { Montpellier Square } & 1824 \text { onwards } \\ \text { Rutland Gate } & 1830 \text { onwards } \\ \text { Beaufort Gardens } & 1840 \text { onwards } \\ \text { Egerton Crescent } & 1843 \text { onwards } \\ \text { Ovington Square } & 1844 \text { onwards } \\ \text { Ennismore Square } & 1849 \text { onwards } \\ \text { Lennox gardens } & 1882 \text { onwards }\end{array}$

The layout of each single urban unit proposes again the same organization of the XVII-XVIII C. squares, infilling the vacant areas between pre existing fabrics.

Every urban unit has its own center, the square, and its edges (the pre-existing routes and the property boundaries); the square is connected to the thoroughfares by one or two streets which represent the main axes of the new development; both the square and the axis are usually built up with homogenous terraced houses characterizing every single estate.

These various urban units, though so similar one another, are not linked together in an organic design and once completed the whole area appears as the simple sum of several different parts.

\section{Conclusion}

Like as the previous analysis of Clerkenwell and Belgravia developments, the present exam of other two great XIX C. developments confirms the existence of two main ways (extensive or intensive as we wrote before) of composing the traditional London's urban fabrics. 
In particular the second one should be further studied and developed as it could give a good answer to the current needs of new residential units, with even more dwellings per hectare than the modern tower blocks tissues and an outcome much more compatible with the pre existing context.

\section{References}

Summerson J. (1945) Georgian London (Yale University Press, New Haven and London).

Pevsner N. (1952) The Buildings of England, London: Except the Cities of London and Westminster (Penguin Books, Harmondsworth).

Summerson J. (1953) Architecture in Britain 1530-1830 (Yale University Press, New Haven and London).

Pevsner N. (1957) The Buildings of England, London: The Cities of London and Westminster (Penguin Books, Harmondsworth).

Benevolo L. (1978) Storia della città (Laterza, Bari).

Maretto P. (1973) Nell'Architettura (Teorema, Firenze).

Krier R. (1975) Stadtraum in Theorie und Praxis (Karl Kramer, Stuttgart).

Caniggia G. (1976) Strutture dello spazio antropico (Uniedit, Firenze).

Godwin G. (1970) History of Urban Form (A.J. Morris, Bath).

Caniggia G., Maffei G.L. (1979) Lettura dell'edilizia di base (Marsilio, Venezia).

Maretto P. (1980) Realtà naturale e realtà costruita (Alinea, Firenze).

Sutcliffe A. (1981) Towards the Planned City (St. Martin's Press, New York).

Caniggia G., Maffei G.L. (1984) Il progetto nell'edilizia di base (Marsilio, Venezia).

Gallarati M. (1994) Architettura a scala urbana - Urban Scale Architecture (Alinea, Firenze).

Hall T. (1997) Planning Europe's Capital Cities (Routledge, London and New York).

Panerai P., Castex J., Depaule J. C. (1997) Formes urbaines: de l'îlot à la barre (Parenthèses, Marseille).

Longstaff-Gowan T. (2012) The London Square (Yale University Press, New Haven and London).
Stern R., Fishman D., Tilove J. (2013) Paradise Planned. The Garden Suburb and the Modern City (The Monacelli Press, New York).

Gallarati M. (2014) 'Towards New Traditional Urban Fabrics: Notes on London's Planned Squares' in Jelenski T., Juchnowicz S., Wozniak-Spakiewicz E. (ed.) Tradition and Heritage in the Contemporary Image of the City (Politechnika Krakowska, Krakow), vol. 2, 53-58. 